\title{
EKSPLORASI KONDISI FISIK DAN NON FISIK PADA PERMUKIMAN PENGOLAHAN HASIL PERIKANAN TRADISIONAL DI KAMPUNG NELAYAN PENGASINAN, MUARA ANGKE
}

\author{
Anisa Anisa \\ Prodi Arsitektur Fakultas Teknik Universitas \\ Muhammadiyah Jakarta \\ anisa@ftumj.ac.id \\ Thoriq Septiawan \\ Prodi Arsitektur Fakultas Teknik Universitas \\ Muhammadiyah Jakarta \\ Gita Laela Nur Rahmah \\ Prodi Arsitektur Fakultas Teknik Universitas \\ Muhammadiyah Jakarta
}

\author{
Kadeli \\ Prodi Arsitektur Fakultas Teknik Universitas \\ Muhammadiyah Jakarta
}

\author{
Syaid Adi Putro \\ Prodi Arsitektur Fakultas Teknik Universitas \\ Muhammadiyah Jakarta \\ Tedi Kurnia \\ Prodi Arsitektur Fakultas Teknik Universitas \\ Muhammadiyah Jakarta
}

\begin{abstract}
Abstrak
Definisi permukiman dalam UU No.1 tahun 2011 adalah bagian dari lingkungan hunian yang terdiri atas lebih dari satu satuan perumahan yang memiliki prasarana, sarana, utilitas umum, serta memiliki penunjang kegiatan fungsi lain dikawasan perkotaan atau kawasan pedesaan. Banyak kita temui permukiman yang mempunyai karakteristik khusus, misalnya berkaitan dengan lokasi, kesukuan, pekerjaan, dll.Salah satunya adalah permukiman nelayan yang ada di Muara Angke. Permukiman ini diberi nama kampung Pengasinan, karena di kampung ini mayoritas penduduknya adalah nelayan yang juga mempunyai aktivitas lain yaitu pengawetan ikan tradisional menggunakan pengasinan (penggaraman). Penelitian ini bertujuan untuk menggali kondisi permukiman nelayan tradisional Kampung Pengasinan Muara Angke.

Penelitian ini menggunakan metode deskriptif kualitatif.Deskriptif kualitatif yang dimaksud adalah mengidentifikasi, mendeskripsikan serta menginterpretasikan kondisi fisik permukiman nelayan tersebut dengan dibantu menggunakan data nonfisik. Analisis dilakukan melalui tiga tahap. Tahap pertama adalah pemilahan data atau sering disebut reduksi data. Tahap kedua adalah tahap klasifikasi. Tahapan ketiga adalah deskripsi dan interpretasi data sampai ditemukan kesimpulan.

Kesimpulan dari penelitian ini adalah, proses terbentuknya sebuah permukiman dan aktivitas yang terjadi di dalamnya akan berpengaruh terhadap bentuk fisik yang dapat diamati. Pemukiman di pengasinan Muara Angke ditata secara terencana oleh badan pengelola hasil perikanan tradisional. Walaupun pola permukiman mereka tertata secara teratur namun, bentuk rumah di pemukiman ini terbentuk menyesuaikan dengan aktivitas atau kegiatan warganya yaitu sebagai pengolah ikan asin. Dapat dilihat bahwa di tengah permukiman terdapat area yang digunakan untuk menjemur ikan yang telah di asinkan, walaupun tempat khusus telah di sediakan.
\end{abstract}

Kata-Kata Kunci: permukiman, pengolahan hasil perikanan, eksplorasi 


\title{
EXPLORATION OF PHYSICAL AND NON-PHYSICAL CONDITION ON TRADITIONAL FISHERY PRODUCTS PROCESSING SETTLEMENTS IN FISHERMEN'S PENGASINAN VILLAGE, MUARA ANGKE
}

\begin{abstract}
The definition of settlements in Law No. 1 of 2011 is part of a residential environment consisting of more than one housing unit that has infrastructure, facilities, public utilities, and has supporting other functional activities in urban or rural areas. Many of us encounter settlements that have special characteristics, such as relating to location, ethnicity, work, etc. One of them is fishermen's settlement in Muara Angke. This settlement was given the name of Kampung Pengasinan, because in this village the majority of the population are fishermen who also have other activities that are preservation of traditional fish using marinating (salting). This study aims to explore the condition of traditional fisherman's settlement of Kampung Mengasinan Muara Angke.

This study used a descriptive qualitative method. Descriptive qualitative in question is to identify, describe and interpret the physical condition of fishing settlements are assisted using nonphysical data. The analysis is done in three stages. The first stage is the sorting of data or often called data reduction. The second stage is the classification stage. The third stage is the description and interpretation of data until found conclusions.

The conclusion of this study is, the process of formation of a settlement and the activities that occur in it will affect the physical form that can be observed. Settlements in Muara Angke salting are laid out in a planned manner by the traditional fisheries management agency. Although the pattern of their settlements arranged regularly, however, the form of houses in these settlements formed to adjust to the activities or activities of its citizens as a salted fish processor. It can be seen that in the middle of the settlement there is an area used to dry the fish that has been in asinkan, although a special place has been provided.
\end{abstract}

Keywords: settlement, processing of fishery products, exploration

\section{Pendahuluan}

Permukiman dalam UU No.1 tahun 2011 adalah bagian dari lingkungan hunian yang terdiri atas lebih dari satu satuan perumahan yang memiliki prasarana, sarana, utilitas umum, serta memiliki penunjang kegiatan fungsi lain dikawasan perkotaan atau kawasan pedesaan. Sedangkan kampung adalah suatu daerah dimana terdapat beberapa rumah atau keluarga yang bertempat tinggal disana. Ada berbagai macam kampung di Jakarta. Beberapa kampung di Jakarta mempunyai karakteristik yang khas, seperti kampung padat perkotaan, kampung etnis tertentu, kampung nelayan, dll. Salah satu kampung nelayan adalah kampung nelayan yang juga merupakan tempat pengolahan hasil ikan atau pengasinan. Kampung ini disebut sebagai kampung Pengasinan Muara Angke. Kampung pengasinan ini terletak di Kelurahan Kapuk Muara, Kecamatan Penjaringan, Kotamadya Jakarta Utara.Lokasinya berdekatan dengan Muara Karang.

Asal nama pengasinan sendiri berasal dari kegiatan warga kampung yaitu pengusaha pembuatan ikan asin. Pengolahan ikan tersebut dilakukan secara tradisional.Dari mulai pengolahan sampai penjualan semua dilakukan secara tradisional.Kampung Pengasinan ini menjadi suatu kampung yang khas dan menarik untuk di teliti, karena latar belakang dari mata pencaharian penghuni kampung sebagai nelayan dan pengolahan hasil perikanan, menjadikan bentuk fisik kampungnya berbeda dengan kampung-kampung yang lain. Berdasarkan latar belakang masalah, maka dapat dirumuskan permasalahan penelitian yaitu: 
1. Bagaimanakah Kondisi fisik dan nonfisik permukiman Pengolahan Hasil Perikanan Tradisional di Kampung Nelayan Muara Angke?

2. Faktor apakah yang mempengaruhi kondisi permukiman tersebut?

Tujuan yang ingin didapatkan dari penelitian ini adalah untuk (1) Mendapatkan gambaran tentang kondisi fisik permukiman nelayan di Kampung Pengasinan seperti bentuk permukiman, pola rumah, dll; (2) Mendapatkan gambaran tentang kondisi non fisik di Kampung Pengasinan seperti mata pencaharian, kehidupan sehari-hari, (3) Mendapatkan kesimpulan tentang faktor yang mempengaruhi kondisi fisik permukiman, misal faktor yang mempengaruhi bentuk rumah dan permukimannya.

\section{Kajian Pustaka}

Kajian pustaka membahas tentang permukiman secara umum dan permukiman nelayan Pengasinan Muara Angke secara khusus

\section{Permukiman}

Saat ini manusia bermukim bukan sekedar sebagai tempat berteduh, namun lebih dari itu mencakup rumah dan segala fasilitasnya seperti persediaan air minum, penerangan, transportasi, pendidikan, kesehatan dan lainnya.Permukiman adalah bagian permukaan bumi yang dihuni manusia meliputi segala sarana dan prasarana yang menunjang kehidupannya yang menjadi satu kesatuan dengan tempat tinggal yang bersangkutan.

Dalam Undang-Undang Nomor 4 tahun 1992 tentang perumahan dan permukiman, perumahan diartikan sebagai kelompok rumah yang berfungsi sebagai lingkungan tempat tinggal atau lingkungan hunian yang dilengkapi dengan sarana dan prasarana. Sedangkan Permukiman adalah bagian dari lingkungan hidup diluar kawasan lindung, baik berupa kawasan perkotaan maupun pedesaan yang berfungsi sebagai lingkungan tempat tinggal atau lingkungan hunian dan tempat kegiatan yang mendukung perikehidupan dan penghidupan.

Dalam UU No.1 tahun 2011 tentang Perumahan dan Kawasan Permukiman dijelaskan bahwa Permukiman adalah bagian dari lingkungan hunian yang terdiri atas lebih dari satu satuan perumahan yang mempunyai prasarana, sarana, utilitas umum, serta mempunyai penunjang kegiatan fungsi lain di kawasan perkotaan atau kawasan perdesaan.Perumahan dan kawasan permukiman adalah satu kesatuan sistem yang terdiri atas pembinaan, penyelenggaraan perumahan, penyelenggaraan kawasan permukiman, pemeliharaan dan perbaikan, pencegahan dan peningkatan kualitas terhadap perumahan kumuh dan permukiman kumuh, penyediaan tanah, pendanaan dan sistem pembiayaan, serta peran masyarakat. Perumahan adalah kumpulan rumah sebagai bagian dari permukiman, baik perkotaan maupun perdesaan, yang dilengkapi dengan prasarana, sarana, dan utilitas umum sebagai hasil upaya pemenuhan rumah yang layak huni. Kawasan permukiman adalah bagian dari lingkungan hidup di luar kawasan lindung, baik berupa kawasan perkotaan maupun perdesaan, yang berfungsi sebagai lingkungan tempat tinggal atau lingkungan hunian dan tempat kegiatan yang mendukung perikehidupan dan penghidupan.Lingkungan hunian adalah bagian dari kawasan permukiman yang terdiri atas lebih dari satu satuan permukiman.

Dapat disimpulkan juga bahwa pemukiman adalah kawasan yang berisi hunian dilengkapi prasarana dan sarana lingkungan dan tempat kerja yang memberikan pelayanan yang mendukung kehidupan.Permukiman ini dapat berupa perkotaan maupun permukiman pedesaan. 


\section{Kampung Nelayan Pengasinan Muara Angke}

Muara Angke adalah pelabuhan kapal ikan atau nelayan di Jakarta. Ditandai dengan dioperasikannya penunjang kebutuhan nelayan seperti pelelangan ikan (struktur dan fasilitasnya) selain kelaziman sebuah bandar yang dikelola seorang Syahbandar. Secara administratif pemerintahan, Muara Angke terletak di kelurahan Kapuk Muara, Kecamatan Penjaringan, Kotamadya Jakarta Utara. Lokasinya berdekatan dengan Muara Karang. Di daerah Muara Angke ini juga terdapat Suaka Margasatwa yaitu kawasan Hutan Bakau 25 Ha yang dihuni oleh sekitar 90 spesies burung. Muara Angke merupakan bagian dari hutan bakau terakhir yang tersisa di Provinsi DKI Jakarta. (Travel around Indonesia, 2016)

Sebagian besar warga di Kampung Kawasan Muara Angke bermata pencaharian pengusaha pengasinan ikan. Usaha ini turun menurun dari orangtua. Hasil produksinya akan dipasarkan ke berbagai wilayah DKI Jakarta, Bekasi, Tangerang, Depok dan Bogor (Julaikah, Nurul dan Farid Hidayat, 2017)

\section{Metode Penelitian}

Penelitian ini menggunakan metode deskriptif kualitatif untuk melakukan eksplorasi terhadap permukiman Nelayan Tradisional Pengasinan Muara Angke. Eksplorasi dilakukan dengan mengamati kondisi permukiman yang meliputi aspek fisik dan non fisik.Kondisi fisik yang dilihat meliputi beberapa hal, pencapaian menuju Kampung Pengasinan, pembagian zona kampung, fasilitas umum, penunjang dan sosial, permukiman nelayan dan denah rumahnya, serta utilitas pada kampung tersebut. Kondisi non fisik yang diamati meliputi aktivitas keseharian yang dilakukan penghuni kampung.

Metode deskriptif kualitatif yang dimaksud adalah mengidentifikasi, mendeskripsikan serta menginterpretasikan kondisi fisik permukiman nelayan tersebut dengan dibantu menggunakan data nonfisik.Pengumpulan data dilakukan melalui observasi lapangan yang dilengkapi dengan wawancara.

Analisis dilakukan terhadap data fisik lapangan, dengan dibantu data nonfisik melalui tiga tahap.Tahap pertama adalah pemilahan data atau sering disebut reduksi data. Sesudah data direduksi, maka data diberikan kode untuk mempermudah proses analisis. Tahap kedua adalah tahap klasifikasi. Pada analisis pengklasifikasian data berdasar kategori yang ditemukan dari observasi dan wawancara. Tahapan ketiga adalah deskripsi daninterpretasi data sampai ditemukan tema-tema temuan. Tema-tema temuan yang berkaitan dengan kondisi permukiman kemudian didialogkan untuk mendapatkan kesimpulan akhir.

\section{Hasil dan Pembahasan}

Pembahasan pada bagian ini meliputi eksplorasi secara fisik dan non fisik. Eksplorasi fisik dimulai dari penyajian data lokasi penelitian dan peta. Eksplorasi aspek fisik pada permukiman nelayan Pengasinan meliputi (1) Pencapaian menuju Kampung Pengasinan Muara Angke; (2) Pembagian zona kampung; (3) Fasilitas Umum, Penunjang dan Sosial; (4) Permukiman nelayan di Pengasinan Muara Angke, termasuk denah rumah; (5) Utilitas pada permukiman. Kondisi non fisik yang diamati dan dianalisis meliputi aktivitas umum dan aktivitas khusus

\section{Lokasi Penelitian}

Lokasi penelitian berada di Kampung Nelayan di Muara Angke.Kampung ini bernama pengasinan yang terletak di Kelurahan Kapuk Muara, Kecamatan Penjaringan, Kotamadya Jakarta Utara.Muara Angke adalah pelabuhan kapal ikan atau nelayan di Jakarta.Ditandai dengan dioperasikannya penunjang kebutuhan nelayan seperti pelelangan ikan (struktur dan fasilitasnya) selain kelaziman sebuah bandar yang dikelola seorang Syahbandar. 


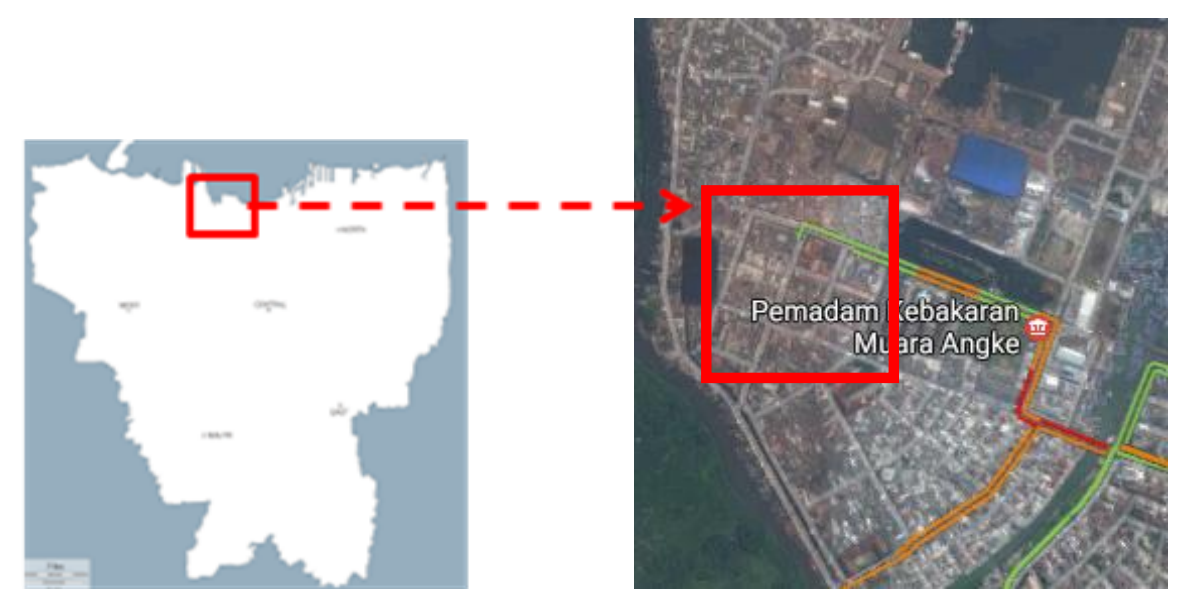

Gambar 1. Peta DKI Jakarta dan Peta Wilayah MuaraAngke Sumber: Google Map, 2018

Permukiman hasil pengolahan tradisional atau PHPT merupakan lahan seluas $64.626 \mathrm{~m}^{2}$ atau 6,2 Ha yang diperuntukkan untuk bermukim warga nelayan yang dilengkapi dengan beberapa fasilitas seperti pelabuhan, pelelangan, dermaga, serta permukiman nelayannya itu sendiri. Luas lahan yang diperuntukkan bagi pemukiman seluas $4.553 \mathrm{~m}^{2}$ atau 0,4 Ha.

Akses menuju site di lewati angkutan umum pada jalan raya utama, untuk menjangkau site dari jalan raya ke lokasi site bisa dengan jalan kaki atau naik ojek. Angkutan umum lain yang menjadi alternatif untuk menuju site adalah Jialing, yaitu sejenis kendaraan beroda tiga pada bagian depan yang berbentuk seperti motor dan bagian belakang menyerupai gerobak yang menampung penumpang 6 hingga 7 orang. Angkutan umum Koperasi wahana kalpika (KWK) dengan angkutan umum dengan jurusan Muara angke - Grogol (B01).

\section{Pencapaian Menuju Kampung Pengasinan Muara Angke}

Untuk pencapaian kedalam site bisa menggunakan kendaraan umum ataupun pribadi, namun bila menggunakan kendaraan umum, kita hannya sampai di depan saja tidak bisa masuk kekawasan permukimannya. Dan sisanya kita harus berjalan kaki melewati pasar ke area pemukiman. 


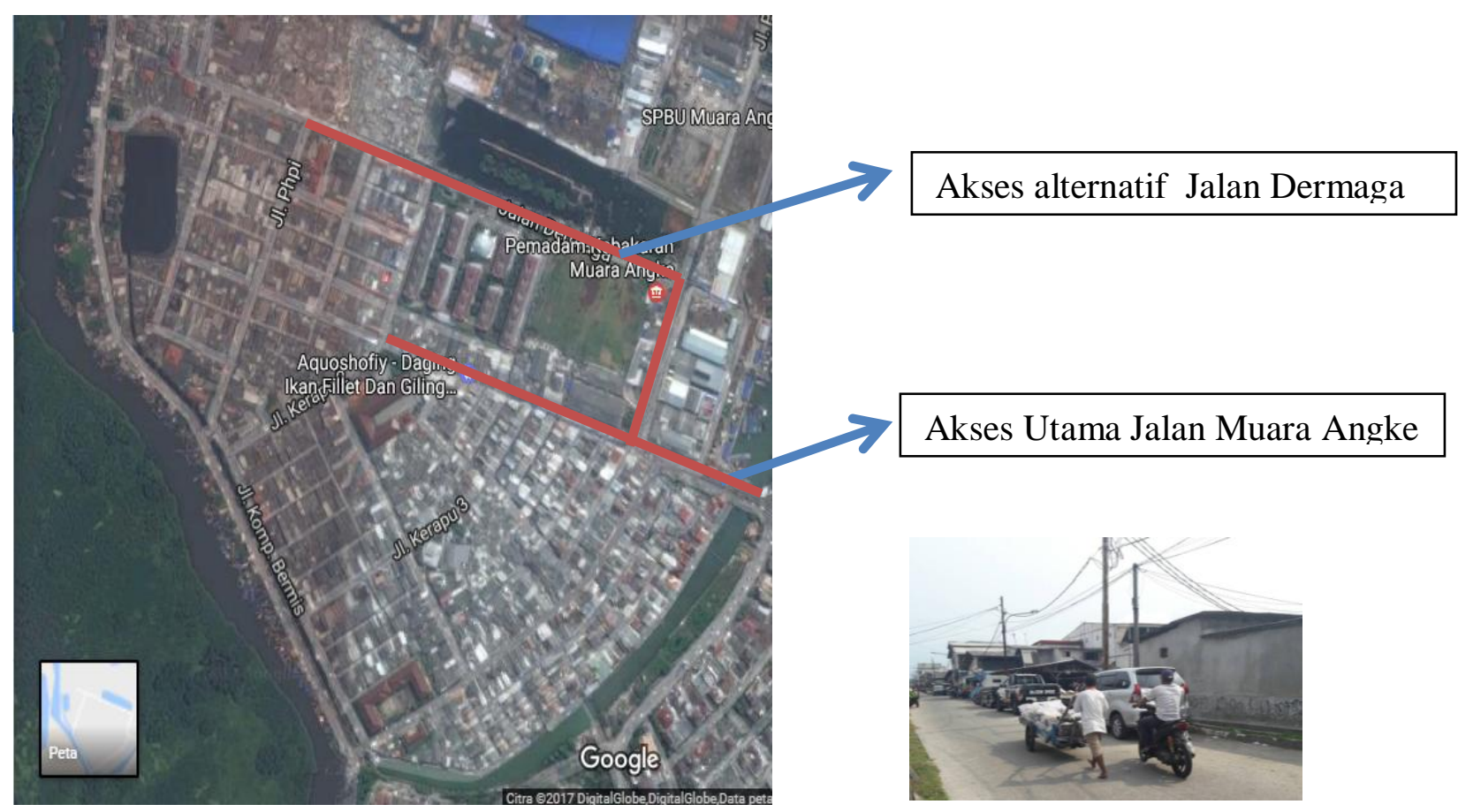

Gambar 2. Peta Wilayah Pencapaian site MuaraAngke Sumber: Google Map, 2018
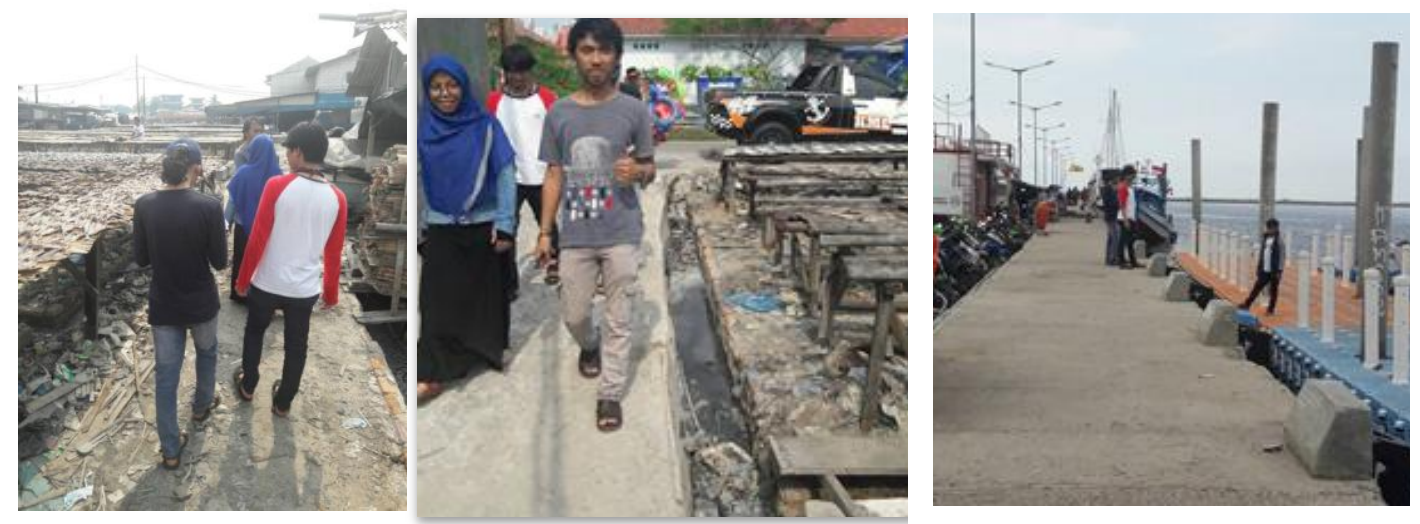

Gambar 3. Akses jalan kaki ke permukiman

Sumber: Observasi Lapangan, 2017

\section{Pembagian Zona Kampung Pengasinan Muara Angke}

Kampung Pengasinan Muara Angke yang direncanakan pembangunannya oleh Badan Pengelola Hasil Perikanan Tradisional, dapat dibagi menjadi beberapa zona yaitu pelabuhan, pelelangan, PHPT (Pengolahan Hasil Perikanan Tradisional), Lapangan, Permukiman, Rusun dan Perumahan Biasa. 


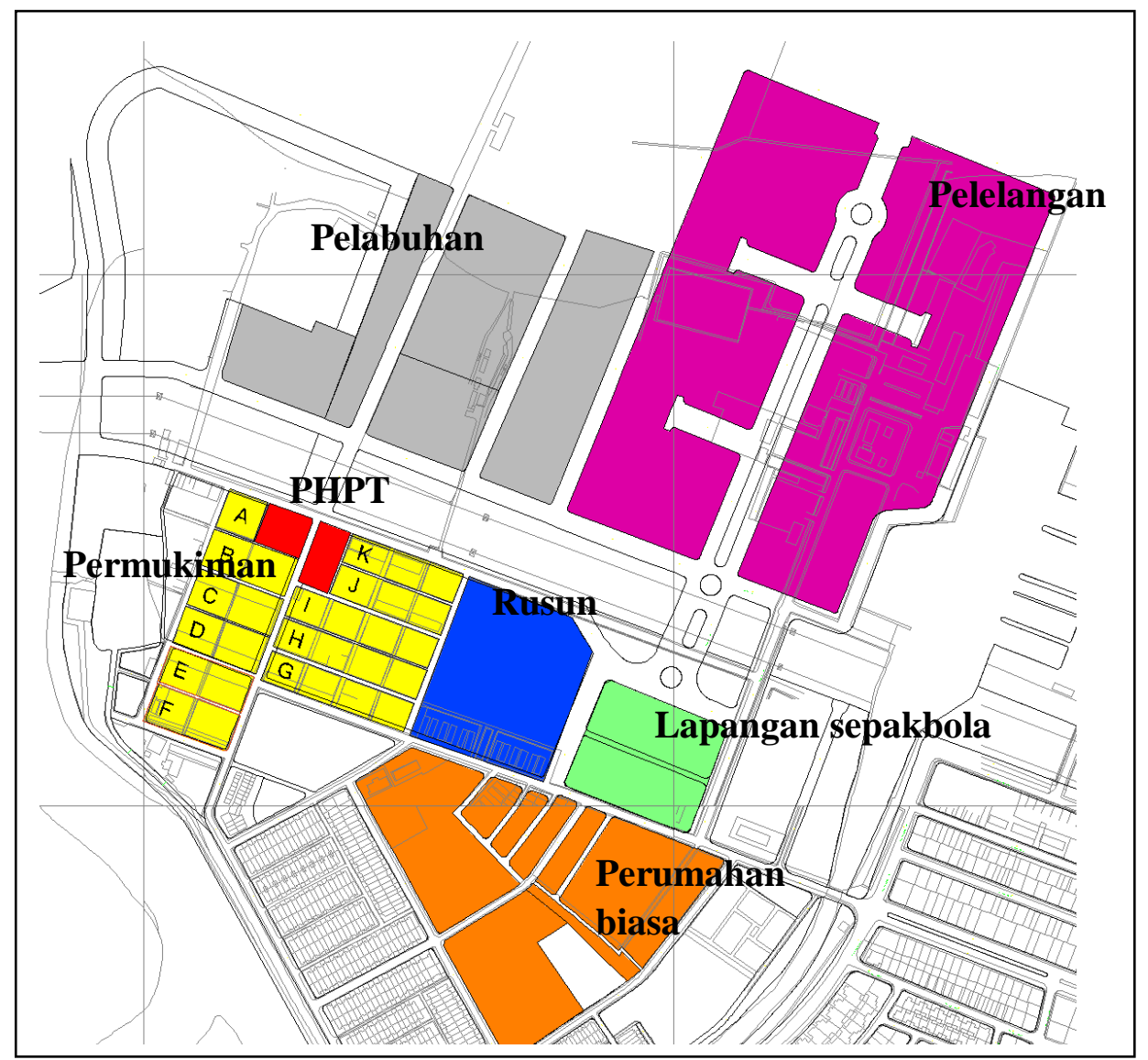

Gambar 4. Pembagian Zona Kampung Pengasinan

Sumber: Observasi Lapangan, 2017

\section{Fasilitas Umum, Penunjang dan Sosial di Kampung Pengasinan Muara Angke}

Fasilitas Umum yang berkaitan dengan perikanan di Muara Angke, tepatnya di pemukiman pengolahan hasil perikanan tradisional ada 3 buah yaitu Pelelangan, PHPT dan Pelabuhan yang dilengkapi dengan dermaga kapal nelayan. Tiga Fasilitas umum tersebut merupakan fasilitas yang penting dan digunakan setiap hari oleh penduduk kampung Pengasinan.
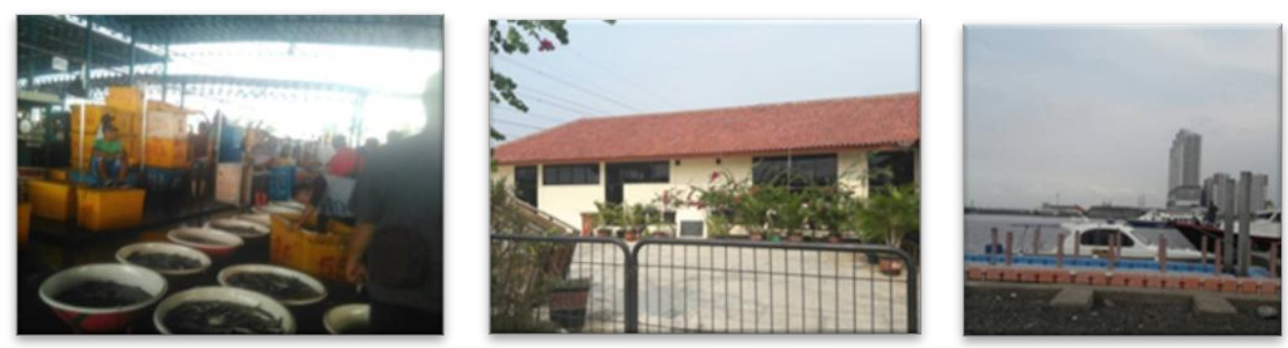

Gambar 5. Fasilitas Umum berkaitan dengan Perikanan Sumber: Observasi Lapangan, 2017

Pada bagian pelelangan ikan, terdapat fasilitas penunjang lain yaitu area jual, bak pengolahan ikan, pelataran ikan asin. Proses sebuah hasil perikanan di mulai dari pelabuhan yaitu setelah ikanikan tersebut di tangkap di perairan, maka pelabuhan menjadi tempat pertama yang digunakan. Di 
Pelabuhan, ikan-ikan sudah mulai dipilah berdasarkan jenis dan ukurannya. Sesudah melewati area pelabuhan, maka pelelangan ikan menjadi bagian utama dari kegiatan penjualan ikan segar. Karena itulah zona pelabuhan dan pelelangan berdekatan karena aktivitas yang terjadi pada dua area tersebut berkaitan erat. Di Pelelangan inilah para pedagang bisa membeli ikan untuk di jual kembali. Selain ikan segar, di kampung Pengasinan ini juga menjual ikan asin atau ikan asap. Ikan asin atau ikan asap merupakan hasil perikanan yang telah melewati proses pengolahan sehingga ikan tersebut bisa disimpan dalam waktu lebih lama. Selain area jual, di pelelangan ada juga bak pengolahan ikan dan pelataran ikan asin atau tempat untuk menjemur ikan setelah melewati proses pengasinan.
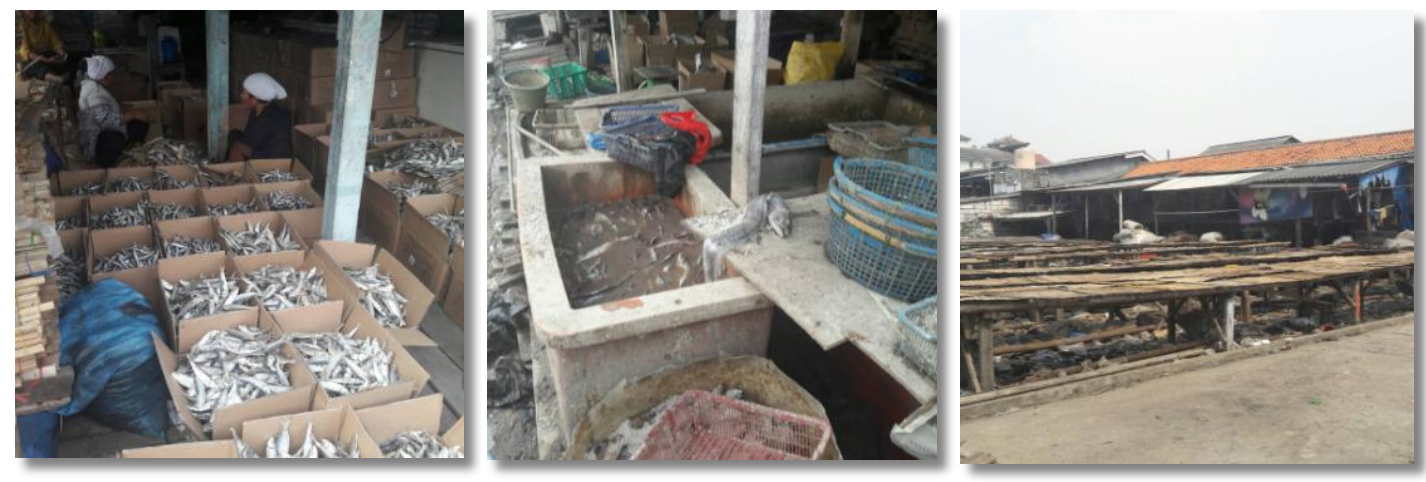

Gambar 6. Fasilitas umum berkaitan dengan Proses Pengolahan hasil perikanan Sumber: Observasi Lapangan, 2017

Selain adanya tiga fasilitas umum di atas, masih ada fasilitas umum lain yang terdapat di Kampung Pengasinan yaitu SMPN 261 Jakarta, Yayasan Nurul Bahri, SDN Pluit 03/05 pagi, 04/06 petang.

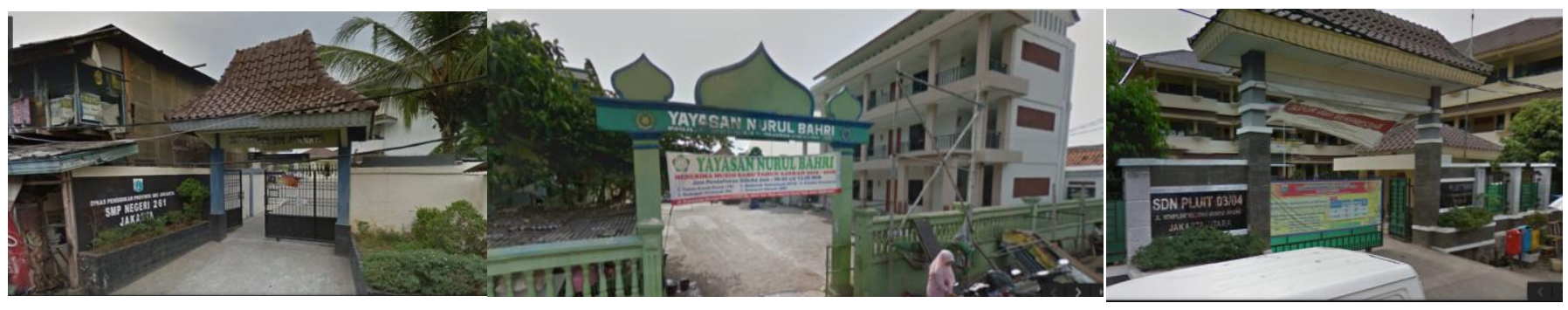

Gambar 7. Fasilitas umum berkaitan dengan Pendidikan

Sumber: Observasi Lapangan, 2017

Fasilitas sosial yang terdapat di area pengasinan ikan adalah mushalla atau masjid, mengingat interaksi sosial dan kegiatan acara besar warga dipermukiman ini biasanya terjadi di mushalla atau masjid 

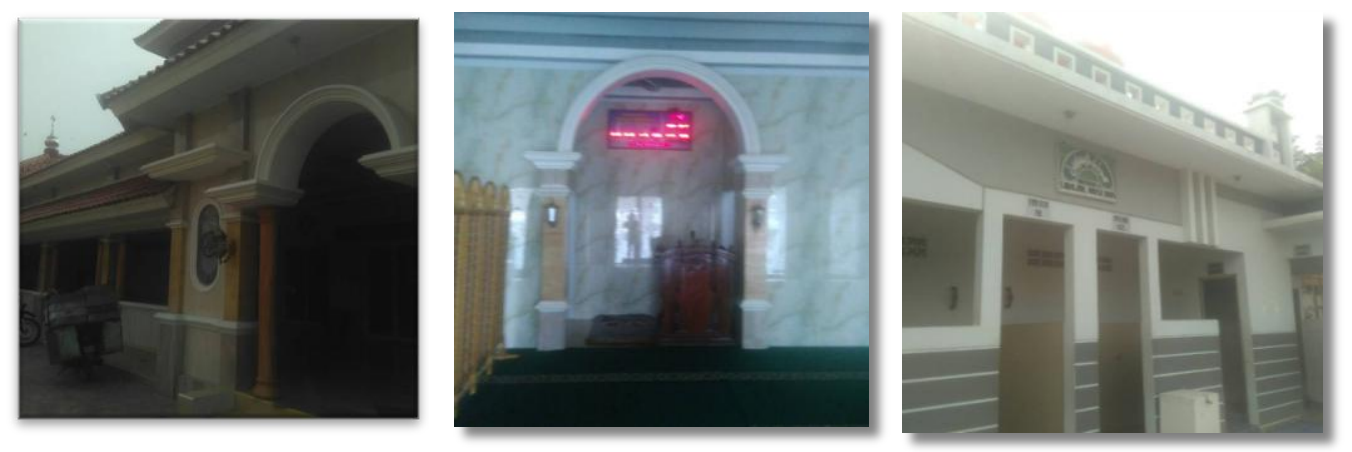

Gambar 8. Fasilitas Sosial

Sumber: Observasi Lapangan, 2017

\section{Permukiman Nelayan di Pengasinan Muara Angke}

Pemukiman Pengolahan hasil perikanan tradisional atau PHPT mempunyai luas total lahan seluas 6,2 Ha. Sedangkan luas lahan untuk permukiman adalah $4.553 \mathrm{~m}^{2}$ atau 0,4 Ha. Berdasarkan survey BPS pada tahun 1990 kepadatan penduduk 5.772 jiwa $/ \mathrm{km}^{2}$ kemudian pada tahun 2000 kepadatan penduduk turun menjadi 5.540 jiwa $/ \mathrm{km}^{2}$, dan pada tahun 2010 kepadatan penduduk meningkat drastis menjadi $6.749 \mathrm{jiwa} / \mathrm{km}^{2}$. Kenaikan jumlah penduduk mengalami kenaikan rata-rata $1,9 \%$ per tahun.

Tabel 1. Kepadatan Penduduk Muara Angke

\begin{tabular}{llll}
\hline Uraian & $\mathbf{1 9 9 0}$ & $\mathbf{2 0 0 0}$ & $\mathbf{2 0 1 0}$ \\
\hline Jumlah penduduk (jiwa) & 262.065 & 251.568 & 306.456 \\
\hline Pertumbuhan Penduduk (\%) & - & $-0,41$ & 1,99 \\
\hline Kepadatan Penduduk & 5.772 & 5.540 & 6.749 \\
\hline Sex ratio (L/P)(\%) & 98,00 & 101,71 & 99,73 \\
\hline
\end{tabular}

Sumber: BPS hasil Survey Penduduk 1990, 2000, 2010

Permukiman penduduk di bagi menjadi tiga yaitu rusun, permukiman terencana dan perumahan biasa. Pada bagian rusun, penduduk hanya bisa menggunakannya untuk tinggal. Namun pada permukiman terencana yang berada di dekat Kantor Pengelola hasil Perikanan Tradisional, jalanjalan yang ada di sekitarnya juga sering digunakan untuk menjemur ikan yang telah diasinkan. Tipologi permukiman pengolahan ini mengikuti pola aktifitas, dimana bagian belakang digunakan untuk mengolah ikan mulai dari merendam ikan, lalu menjemur ikan dipelataran dan dibagian depan rumah difungsikan utuk menjual hasil pengolahan pengasinan ikan. kondisi jalan penghubung antar rumah yang hanya bisa dilalui 2 orang bersimpangan dengan lebar $\pm 120 \mathrm{~cm}$. Selain itu, ada beberapa jalan didalam permukiman masih berbentuk tanah yang hanya ditimbun puing-puing bangunan dengan kontur yang tidak merata sehingga ketika hujan sering menjadi genangan air.

Pola aktifitas didalam permukiman pengolahan ikan bermula ketika nelayan membawa hasil tangkapan laut yang langsung diangkut ke loading yang ada di dermaga pelelangan, ketika hasil tangkapan laut siap didistribusikan nelayan kemudian membawa hasil laut ke pengolah di pemukiman pengasinan ikan.Setelah itu, pengolah ikan asin mengolah hasil laut di bak perendaman ikan asin yang berada di teras belakang. Setelah selesai proses perendaman ikan asin, selanjutnya proses penjemuran dipelataran belakang rumah. Setelah selesai proses pengeringan, pengolah membawa hasil olahannya ke bagian depan rumahnya untuk di kemas dan dijual. Dari proses inilah pola aktifitas pemukiman kampung pengolahan ikan tradisional terjadi. 

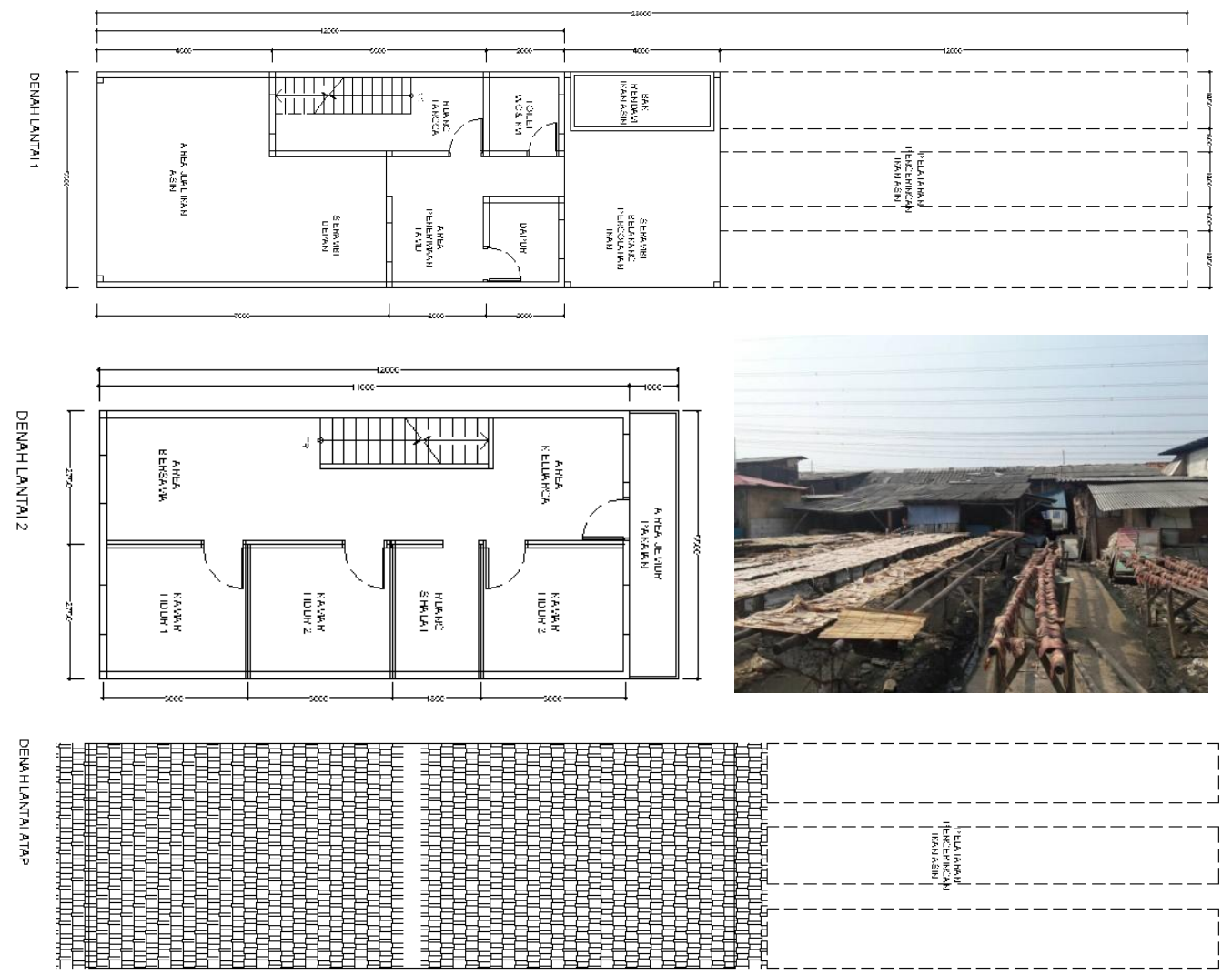

Gambar 9.Tipologi Permukiman

Sumber: Observasi Lapangan, 2017

Matahari dan lintasannya sangat berpengaruh pada permukiman ini. Lintasan matahari mempengaruhi orientasi bangunan, serta tata letak bukaan pada bangunan yang harus menghadap ke utara atau selatan yang bertujuan mengurangi silau karena matahari sore dari arah barat, yang jika terpaksa tata letak bangunan tersebut maka solusi desainnya menggunakan tanaman gantung atau pohon-pohon untuk mengurangi efek sinar matahari. Ditambah permukiman pengolahan ikan di Muara Angke yang dekat dengan laut menambah suasana yang sangat terik serta tidak banyak lahan hijau di area tersebut.

Kawasan pemukiman pengasinan berada di pinggir laut sehingga kecepatan angin sangat tinggi.Puncak tertinggi kecepatan angin yaitu malam hari dan siang hari yaitu saat terjadi angin darat dan angin laut. Upaya yang dilakukan untuk menangani hal tersebut, warga pengasinan mendesain rumah mereka dengan memberikan kisi-kisi di atap rumah mereka sebagai sirkulasi udara.

Karena permukiman pengolahan ikan di Muara Angke adalah kawasan permukiman yang cukup padat, dimana faktor utamanya karena letak geografis yang berada dipingir kota yang kemudian ditambah dengan moda transportasi air yang dekat dengan kawasan, serta adanya pelelangan ikan ditengah pemukiman yang beroperasi 24 jam membuat kawasan tersebut selalu ramai. Namun, karena warga dipermukiman memang kebutuhan warga pengolah ikan yang menunggu nelayan datang dari menangkap ikan di laut antara pukul 02.00 wib hingga pukul 05.00 pagi, membuat warga terbiasa dengan pola pemukiman yang lainnya, yang biasanya pemukiman lain digunakan untuk bertistirahat. 


\section{Utilitas pada Permukiman}

Kurang baiknya drainase mulai dari kawasan permukiman warga hingga drainase di pengasinan ikan yang kurang terintegrasi dengan baik ke saluran utamanya. Serta kurang pedulinya warga terhadap pengolahan/pembuangan limbah olahan ikan yang dibiarkan mengotori drainase. Drainase di kawasan pemukiman juga sangat kecil \pm lebar $30 \mathrm{~cm}$ dengan kedalaman $\pm 30 \mathrm{~cm}$ kurang mampu untuk menampung semua aktivitas warga, ditambah dengan banyaknya endapan lumpur dan banyaknya sampah yang membuat drainase kurang berfungsi dengan baik.

Pengelolaan limbah sampah yang kurang baik di pengolahan pemukiman hingga tingkat penjemputan sampah dari tempat pembuangan sampah sementara, ke pembuangan sampah akhir, tergolong kurang intens, sehingga mengakibatkan menumpuknya sampah yang menimbulkan bau tak sedap. Hal tersebut mengganggu kenyamanan warga pemukiman yang melewati bak sampah tersebut. Terkadang sampah yang terlampau menumpuk membuat semakin sempitnya jalan sehingga jalan menjadi macet.
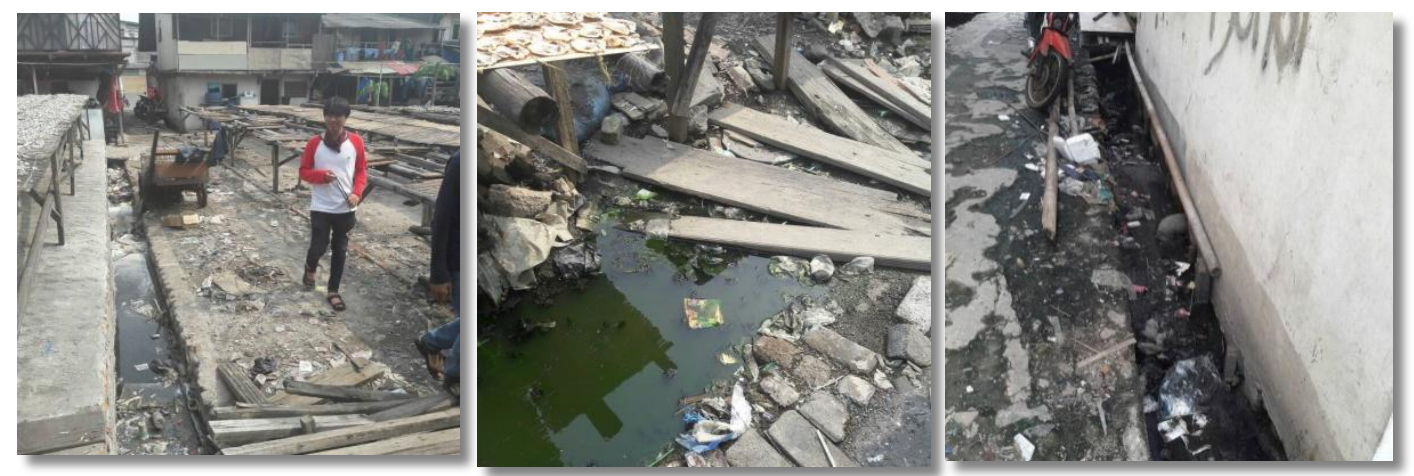

Gambar 10. Kondisi Drainase

Sumber: Observasi Lapangan, 2017

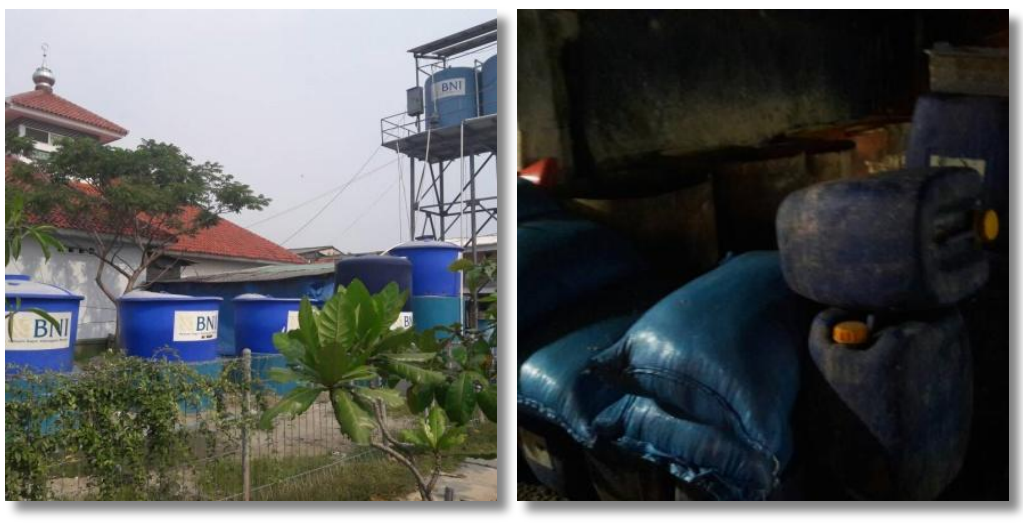

Gambar 11. Air Bersih

Sumber: Observasi Lapangan, 2017

Untuk kebutuhan air bersih di permukiman pengolahan ikan asin banyak menggunakan PAM dan air sumur. Warga sangat tergantung pada air PAM karena air sumur di Muara Angke yang notabene sangat dekat dengan laut terkontaminasi dengan air asin yang kurang cocok digunakan untuk kebutuhan sehari-hari warga. Di permukiman pengolahan ikan juga terdapat beberapa WC Umum sebagai sumber air bersih yang biasa warga gunakan untuk mencuci dan mandi. Meski ada pengolahan air bersih yang baru dibangun oleh pihak swasta namun kurang mencukupi kebutuhan 
warga karena cakupannya masih sedikit. Sehingga banyak warga yang tidak mendapat air bersih harus membeli air bersih melalui derigen-derigen kecil.

\section{Aktifitas Umum}

Mayoritas warga adalah penduduk lama yang bermukim di wilayah tersebut. Sebagian/beberapa berasal dari luar kota, penduduk pendatang didominasi orang Indramayu yang memiliki latar belakang pencaharian sebagai Nelayan. Kegiatan sosial kemasyarakatan yang terjadi adalah ketika ada acara keagamaan atau hari raya besar biasanya dilakukan di mushalla atau masjid setempat. Sehingga fenomena yang kami temui setiap beberapa meter selalu ditemui masjid/ mushalla.

Kegiatan sosial masyarakat yang lain yaitu ketika ada acara pernikahan, khitanan, atau budaya tahlilan itu dilakukan di rumah warga yang bersangkutan. Dengan membuat panggung didepan rumah ataupun ritual doa di rumah warga yang bersangkutan tersebut. Kegiatan sosial lain yang kami temui adalah eratnya kerja bakti atau gotong royong antar warga, sebagai contoh ada beberapa ibuibu yang sedang memasak membantu salah satu warga yang sedang menggelar acara.

\section{Aktifitas Khusus}

Kebudayaan masyarakat yang terdapat dipemukiman pengasinan adalah :

1. Ketika ada acara pernikahan maupun khitanan masyarakat dipemukiman ini biasanya menggelar acara besar-besaran yang mengundang tetangganya. Biasanya pesta acara yang dilakukan adalah dengan menggelar dangdut tarling, maupun hingga doa bersama.

2. Kebudayaan lainnya adalah ketika tetangganya memiliki acara pesta khitanan maupun pesta pernikahan, umumnya ibu-ibu dipemukiman ini melakukan sukarela gotong royong memasak bersama.

\section{Interpretasi hasil Eksplorasi}

Setelah mendapatkan data fisik dan non fisik melalui observasi lapangan dan wawancara, maka data tersebut dianalisis satu persatu. Analisis dilakukan tiap bagian data yang ditemukan karena ini adalah penelitian eksplorasi. Misalnya pada bagian pencapaian menuju Kampung Pengasinan, didapatkan data bahwa kampung ini dapat diakses menggunakan kendaraan umum dan kendaraan pribadi. Pemerintah menyediakan kendaraan umum menuju kampung ini karena di dalamnya terdapat fasilitas yang menunjang aktivitas nelayan yaitu pelabuhan, pelelangan dan pengolahan hasil perikanan. Data ini didapat dari eksplorasi mengenai fasilitas umum berkaitan dengan perikanan. Jadi dalam melakukan eksplorasi, antar data didialogkan terlebih dahulu, baik berupa data fisik dan non fisik kemudian ditafsirkan atau diinterpretasikan.

\section{Kesimpulan}

Pemukiman di pengasinan Muara Angke tidak seperti kampung nelayan lain yang berkembang secara organik. Pemukiman ini ditata secara terencana oleh badan pengelola hasil perikanan tradisional. Walaupun pola permukiman mereka tertata secara teratur namun, bentuk rumah di pemukiman ini terbentuk menyesuaikan dengan aktivitas atau kegiatan warganya yaitu sebagai pengolah ikan asin. Walaupun pola permukiman mereka tertata secara teratur namun, bentuk rumah di pemukiman ini terbentuk menyesuaikan dengan aktivitas atau kegiatan warganya yaitu sebagai pengolah ikan asin. Dapat dilihat bahwa di tengah permukiman terdapat area yang digunakan untuk menjemur ikan yang telah di asinkan, walaupun tempat khusus telah di sediakan.Jadi dapat disimpulkan bahwa faktor yang mempengaruhi kondisi permukiman tersebut adalah:

a. proses terbentuknya sebuah permukiman

b. aktivitas yang terjadi di dalam permukiman tersebut 


\section{POLA AKTIVITAS}

PEMUKTMAN PENGOLAHAN HASIL PERIKANAN TRADISIONAL: KAWASAN KAMPUNG NELAYAN, MUARA ANGKE

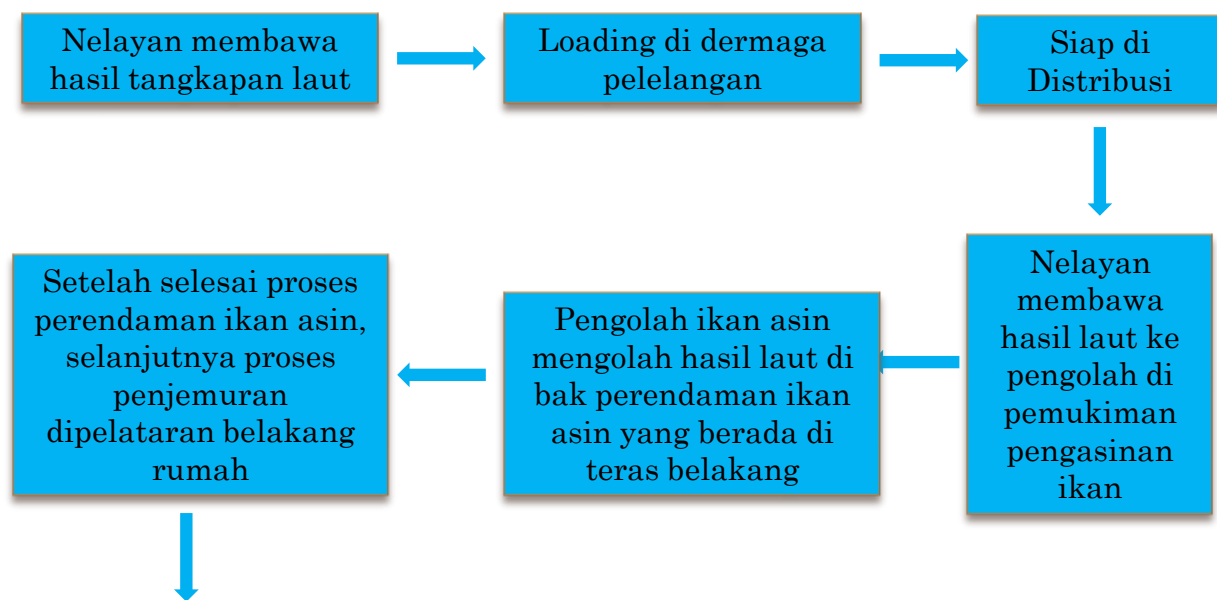

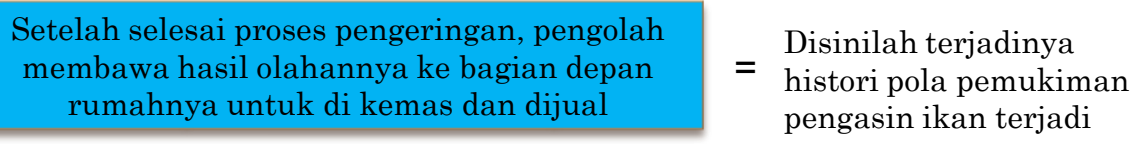

\section{Gambar 12. Pola Aktivitas Penduduk Kampung Pengasinan Sumber: Analisis, 2018}

\section{Daftar Pustaka}

BPS. 1990. Data Statistik Muara Angke BPS. 2000. Data Statistik Muara Angke BPS. 2010. Data Statistik Muara Angke

Julaikah, Nurul dan Farid Hidayat. (2017). Menelisik Pengrajin Ikan Asin di Muara Angke. http://m.infonitas.com/pluitkapuk/usaha/menelisik-pengrajin-ikan-asin-dimuara-angke/51017. 3 Juni 2018.
Travel Around Indonesia. (2016). Muara Angke, Sebuah Pemukiman Nelayan yang Terlupakan. http://seetheworldonamonitor.blogspot.com/201 6/12/muara-angke-sebuah -pemukimannelayan.html.3 Juni 2018

Undang-undang No.1 tahun 2011 tentang Perumahan dan Kawasan Permukiman

Undang-Undang Nomor 4 tahun 1992 tentang perumahan dan permukiman 